\title{
The Determinants of Lecturers' Classroom Management as Depicted in Their Teaching Performance
}

\author{
Didik Rinan Sumekto ${ }^{1}$, Heny Setyawati ${ }^{2}$ Tukiyo $^{3}$, Ronggo Warsito ${ }^{4}$
}

\footnotetext{
1 Widya Dharma University, English Education Department, Jl. Ki Hajar Dewantara, Klaten Utara, Klaten, Indonesia, didikrinan@unwidha.ac.id

2 Semarang State University, Physical Education Department, Kampus Sekaran, Gunungpati, Semarang, Indonesia, henysetyawati@mail.unnes.ac.id

3 Widya Dharma University, Javanese Education Department, Jl. Ki Hajar Dewantara, Klaten Utara, Klaten, Indonesia, tukiyo@unwidha.ac.id

4 Widya Dharma University, Civics Education Department, Jl. Ki Hajar Dewantara, Klaten Utara, Klaten, Indonesia,warsito@unwidha.ac.id
}

\begin{abstract}
This study aims at assessing four determinants of lecturers' classroom management practices, in which 215 or $18.69 \%$ respondents participated in this study. Data analyses used descriptive statistics, Pearson correlations and regression analysis with the significance level of .05 . The results showed that the conduciveness $(t=2.992 ; \mathrm{p}=.003)$, diversity acceptance $(\mathrm{t}=3.243$; $\mathrm{p}=.001)$, disciplines engagement $(\mathrm{t}=3.968 ; \mathrm{p}=.000)$, and corrective decision $(\mathrm{t}=3.045 ; \mathrm{p}=.003)$ partially contributed positive and significant influence towards lecturers' $28.8 \%$ teaching performance, where $\mathrm{F}=21.209 ; \mathrm{R}^{2}=.288 ; \mathrm{p}<.000$. The analysis discloses two-tailed regression with $\mathrm{Y}=12.660+.225 \mathrm{X} 1+.175 \mathrm{X} 2+.237 \mathrm{X} 3+.142 \mathrm{X} 4$.
\end{abstract}

Keywords: conduciveness, corrective decision, disciplines engagement, diversity acceptance.

\section{Introduction}

A cozy classroom creation will support a good classroom management since this condition accomplishes lecturers' professional attitude in creating and maintaining the classroom climate in order to encourage students learn good behavior. The classroom management effectiveness will depend on how lecturers can understand its implemen- 
tation aspects daily. These aspects can be traced from the curriculum, teaching methodology, learning media, and pedagogical affairs that implicate the success of classroom learning processes. Other aspects are also influenced by lecturers' sympathetic personality, students' impressed learning experience, and globally knowledgeable lecturers who implicitly indicate the obtainable learning objectives. In this situation, Lenaerts, Braeye, Nguyen, Dang, and Vromant (2017) state that higher education students will prepare themselves to learn with the substantial roles in fostering their learning development, expressing experience, and nurturing interactions and relationships through various neuro-scientific perspectives. These roles shall have relied on significant relationships: learning with peers and learning with a skillful and experienced lecturers (Barak, 2017). This purpose is to reflect on their internal dialogues, carrying on nonconstructive-based thoughts into constructive and inspiring thoughts to give feedback as part of the learning designs (Reinke, Stormont, Webster-Stratton, Newcomer, \& Herman, 2012) along with lecturers.

So, beyond simply being constructive, both lecturers and students must be trustful of having possible consequences with the transcended ways as their self-efficacy depend on their satisfaction and relationships (Romi, Lewis, \& Roache, 2013). Pointedly, when lecturers play various roles in a certain classroom, they become the most important agents of changes among students (Marzano, Marzano, \& Pickering, 2003). They act like 'the actor' and accommodates any resources to motivate and give challenges to students (Ivanov, 2014). Lecturers' capacity attempt to accommodate students' learning maturation (Sumekto \& Setyawati, 2020) and to encourage their cognitive acceleration, inclination, and open-mindedness (Sumekto, 2017), besides undertaking a pedagogical paradigm in recent years to stimulate students' impetus, attainment, and self-determination (Fernandes, Flores, \& Lima, 2012; McCabe \& O’Connor, 2014).

\section{Theoretical Background}

In this case, lecturers with highly applicable and developed skills attempt to work harder for students' classroom management performance betterment, either academically or non-academically achievements to all students (Webster-Stratton, Reid, \& Stoolmiller, 2008). This relates to lecturers whose expertise in exploring their class circumstances and draws on a special range of classroom management performance. Somehow, abound trust between lecturers and students will be the mutual commitment of the classroom climate (Wright, 2005) and respectful relations as part of the effort to encourage study and cultivate an appropriate behavior in the classroom (Tal, 2010) toward the collaborative-based efforts that promote and engage in both lecturers and students (McAfee, 2015). Flexibly, some efforts may match with students' individual-based performance to refine their independent problem-solving capacity, enhance and improve the use of any 
language skills (Sumekto \& Setyawati, 2018). So far, collaborative learning is regarded as meaningful ways of improving classroom (Wright, 2005). One of the ways is granted from lecturers' resilience that involves de-personalizing difficult events by concisely resuming through what is happening in the classroom. The resilience can be concreted in lecturers' sense of multiple purposes emphasizing students' cognitive and non-cognitive domains (Romi, Lewis, \& Roache, 2013). A well-managed classroom is needed for lecturers who simultaneously determine the rules and procedures, and set up the rewards system following students' participation and discipline to reinforce positive behaviors regarding the improper and violent manner (Marzano, Gaddy, Foseid, Foseid, \& Marzano, 2005).

Currently lecturers' classroom management requires proactive and ecological perceptiveness of the classroom activity and need good interpersonal relations with students to constantly and reflectively manage oneself (Tal, 2010), since the classroom management identification is substantial in order to promote humanistic and positive styles of both lecturers and students (Chambers \& Hardy, 2005). Selçuk, Kadi, Yildirim, and Çelebi (2017) agree that classroom management conveys the creation and maintenance of an environment for students' learning suitability. Its dimensions relate to determining the rules to be obeyed, effective time, teaching management, and controlling students' behaviors to create the most suitable learning atmosphere. According to Romi, Lewis, and Roache (2013), the approaches and processes produce positive behavioral changes and prevent discipline problems. But, on the other hand, low-quality classroom management may complicate either lecturers or students' difficulties (Garwood \& Feagans, 2017). For instance, the phenomenon of higher education students' complaints and unsatisfactions upon lecturers' EFL classroom management performance addresses the crucial problem. This generally relates to classroom's ineffective learning experience, as well as corresponding with students's and lecturer's insufficient interaction and communication. So far, they are involved in a big class, besides unwilling students to take participations and lecturers' static teaching styles.

Therefore, the successful teaching engagement in students' classroom management effectiveness shall require a substantial level of self-awareness (Shindler, 2010) to optimize lecturer-students relationships (Korpershoek, Harms, de Boer, van Kuijk, \& Doolaard, 2014). The higher the quality of lecturers' self-awareness is, the more focused lecturers' intentions can trigger (Shindler, 2010). It means that classroom management performance can be awarded from lecturers' skills, knowledge, and self-confidence around interdisciplinary collaboration (Noy, Patrick, Capetola, \& McBurnie, 2017). This includes lecturers' disposition to accurately identify potential misbehavior and to immediately act on it without getting frustrated (Korpershoek, Harms, de Boer, van Kuijk, \& Doolaard, 2014). So, the classroom management proposes the effectiveness of the dynamic measure including the ability to modify classroom activities into well-being (Tal, 2010), such as nurturing, encouraging, and motivating students (Webster-Stratton, Reinke, Herman, \& Newcomer, 2011). 
As we believe that a good classroom management views a conditional students' learning, accomplishes lecturers fix the important instructional goals (Emmer \& Stough, 2001), engages students dealing with the emotional supports effectively (Garwood \& Feagans, 2017), and creates a more stable learning environment for students (McAfee, 2015). However, there are four factors delivering the effective classroom management, such as rules and procedures, disciplinary interventions, a relationship between lecturers and students, and mental set (Marzano, Marzano, \& Pickering, 2003) to initiate students' learning creation and circumstance appeal (Korpershoek, Harms, de Boer, van Kuijk, \& Doolaard, 2014). When lecturers acknowledge the classroom management techniques, some facts show the level of learning processes through students' seating positions that mostly influence the classroom (Eisenman, Edwards, \& Cushman, 2015). For instance, Figure 1 may flexibly alter lecturers' classroom management settings when demonstrating their classroom-based teaching. These seating alternatives lead to some positions as being available to do. The circle type is available to use in the room and the horseshoe type is popularly available for higher education students. Meanwhile, the seminar-type or rectangle position relates to a variance in the cabinet meeting and the semi-circle type is normally accommodated for small classes.
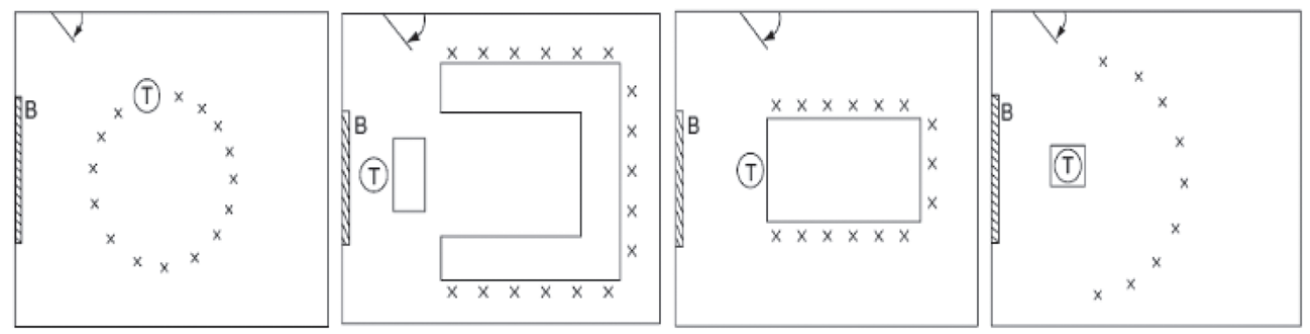

Figure 1. Lecturers' Classroom-Based Teaching Management (modified from Wright, 2005)

\section{Previous Studies}

Numerous studies on lecturers' classroom management had supported effective classroom management became a significant impact on students' attainment and worth as the main indicator (Romi, Lewis, \& Roache, 2013). Further, Selçuk, Kadi, Yildirim, and Çelebi (2017) released that the class had a significant effect on students' attitudes toward competencies in classroom management. The acceptability and satisfaction of classroom management permitted students to alter their practice and felt more confident in applying the strategy (Marlow, Hansford, Edwards, Ukoumunne, Norman, Ingarfield, Sharkey, Logan, \& Ford, 2015). The notion of an underlying latent constructed specified between male and female students in the types of behaviors they exhibited significantly, where male students were rated higher on externalizing behaviors, whilst female students were rated higher on internalizing behavior. Nevertheless, there was no significant difference 
found in the classroom management quality involving both male and female students (Garwood \& Feagans, 2017). Other studies also reported that students' obedience to rules and procedures, disciplinary interventions, mutual relationships, mental set, and students' responsibility contributed to the classroom management determinants. These classroom management aspects supported that the most common combination related to a combination of students' behavior and social-emotional development focuses on their lecturer in the classroom (Korpershoek, Harms, de Boer, van Kuijk, \& Doolaard, 2014).

\section{Problem Formulation and Objectives}

Stepping ahead into lecturers' classroom management performance, the condition may influentially undertake from the focused disciplines on lecturers' personal and disciplinary identity, values, and qualifications. These disciplines definitely bring about the broader collaborations between lecturers and students in day-to-day learning processes sustainably. This study focuses lecturers' classroom management performance with the following research questions: Do lecturers' conduciveness, diversity acceptance, disciplines engagement, and the corrective decision upon students' inappropriate manner partially and collectively have a positive and significant influence on lecturers' teaching performance? However, this study aims at assessing the influencing determinants of lecturers' teaching performance that are perceived by the higher education students.

\section{Materials and Methods}

\section{Design}

This study used the descriptive quantitative method that analyzed the substantial issues of lecturers' classroom management performance at the English Education Department by addressing four predictors as the independent variables, namely: the conduciveness of physical and socio-emotional learning atmosphere, the diversity of stating the agreeableness to other educational backgrounds, the disciplines engagement when using time allotment, and the corrective decision on students' inappropriate manner during the English classes, and one dependent variable of lecturers' teaching performance.

\section{Data collection and sample size}

Data were carried out from the self-rated questionnaire distribution regarding pre-service English teachers' perceptions upon lecturers' teaching performance. This study used the interval data by converting into a 5 point Likert scale, ranging from 5 to $1(5=$ excellent $; 4=$ good; $3=$ fair, $2=$ unsatisfied, $1=$ poor $)$. This study was conducted at a private university in Yogyakarta, Indonesia whose core education policy was affiliated 
with Muhammadiyah, one of the largest Islamic organizations in Indonesia. Of 1.054 population, 215 pre-service English teachers were randomly selected to be the respondents. They were accordingly $65 \%(n=139)$ as female and $35 \%(n=76)$ as male participants when filling in the questionnaire. The respondents' age ranged in between 18 to 23 years old (Mage $=20.5 ; S D=3.53$ ).

The sample size determination used Cohen's formulation. The value was determined through the significance level (a), power (1-b), number of variables (U), and effect size $\left(f^{2}\right)$. The formulation was $\mathrm{N}=\mathrm{L} / f^{2}+\mathrm{U}+1$, where $\mathrm{N}=$ sample size, $\mathrm{L}=$ non-centralization parameter, $f^{2}=$ effect size, and $\mathrm{U}=$ number of variables. The non-centralization parameter value was gained from Table 9.4.2 (Cohen, 1977), which referred to 15.40 and $f^{2}=.15$ (minimal value), and $1-b=.90$ at the significance level (a) of .05 adopting 4 variables. The formulation relied on $\mathrm{N}=15.40 \div .15+4+1 ;=102.66+4+1=107.66$ (decimalized into 108). Hence, the minimal sample size (N) was 108 respondents. The final decision to undertaking the sample size was 215 or $18.69 \%$ of pre-service English teachers.

\section{Validity and reliability}

The questionnaire was preliminary tested through Cronbach's alpha reliability coefficients to standardize the value of alpha ( $\alpha$ ). The alpha's criteria should be greater than $(>60)$ to be considerably reliable (Ghozali, 2001). The alpha $(\alpha)=.786 ; M=13.94$; and $S D=1.90$ for lecturers' teaching performance $(\mathrm{Y})$, whilst the predictors or independent variables $\left(\mathrm{X}_{1}, \mathrm{X}_{2}, \mathrm{X}_{3}\right.$, and $\left.\mathrm{X}_{4}\right)$ score ranged in between .625 to .819 with the sample size of thirty-five pre-service English teachers. The values dealt with the predictors of conduciveness of physical and socio-emotional learning atmosphere $(\alpha=.694 ; M=14.94$; $S D=1.83)$, the diversity of stating the agreeableness to other educational backgrounds $(\alpha=.819 ; M=14.37 ; S D=2.46)$, the disciplines engagement when using time allotment $(\alpha=.625 ; M=15.23 ; S D=1.99)$, and the corrective decision upon students' inappropriate manner $(\alpha=.676 ; M=14.80 ; S D=2.49)$.

\section{Data analysis}

Data were analysed through the Pearson correlations (Pearson $r$ ), descriptive, inferential, and regression analysis. The descriptive analyses specified mean $(M)$ and standard deviation $(S D)$, whereas the inferential analysis examined the hypothesis $\mathrm{X}_{1}, \mathrm{X}_{2}, \mathrm{X}_{3}$, and $\mathrm{X}_{4}$. Meanwhile, the standard multiple regression analyses were used to analyze four predictors, namely: the conduciveness of physical and socio-emotional learning atmosphere $\left(\mathrm{X}_{1}\right)$, diversity of stating the agreeableness to other educational backgrounds $\left(\mathrm{X}_{2}\right)$, the disciplines engagement when using time allotment $\left(\mathrm{X}_{3}\right)$, and the corrective decision upon students' inappropriate manner $\left(\mathrm{X}_{4}\right)$. The regression equivalence was $\mathrm{Y}=\mathrm{a}+\mathrm{b}_{1} \mathrm{X}_{1}+$ $\mathrm{b}_{2} \mathrm{X}_{2}+\mathrm{b}_{3} \mathrm{X}_{3}+\mathrm{b}_{4} \mathrm{X}_{4}$, where $\mathrm{Y}=$ lecturer's teaching performance; $\mathrm{a}=$ constant ( $\mathrm{Y}$ value if $\mathrm{X}=0$ ); $\mathrm{b}_{1}, \mathrm{~b}_{2}, \mathrm{~b}_{3}, \mathrm{~b} 4=$ regression coefficients; and $\mathrm{X}=$ predictor. 


\section{Results}

\section{Descriptive analysis}

The preliminary descriptive analyses focused on a single dependent variable and four predictors as the independent variables that were summarized into the following frequencies and percentages (Table 1). First, the scores resulted from the positive end of the categories, such as excellent to unsatisfied within a range of 42 to $74(M=57.05$; $S D=4.660)$ for the conduciveness of physical and socio-emotional learning atmosphere ( $\left.\mathrm{X}_{1}\right)$. Of 215 respondents, 8 or $3.7 \%$ respondents answered excellent, 83 or $38.6 \%$ respondents answered good, 108 or $50.2 \%$ respondents answered fair, and 16 or $7.4 \%$ respondents answered unsatisfied towards lecturers' conduciveness of physical and socio-emotional learning atmosphere in the classroom.

Table 1

Conduciveness of Physical and Socio-Emotional Learning Atmosphere

\begin{tabular}{lrrr}
\hline \hline Likert" s Scale & Frequency & Percent & Valid Percent \\
& & & \\
\hline 5.00 (Excellent) & 8 & 3.7 & 3.7 \\
4.00 (Good) & 83 & 38.6 & 38.6 \\
3.00 (Fair) & 108 & 50.2 & 50.2 \\
2.00 (Unsatisfied) & 16 & 7.4 & 7.4 \\
$\quad$ Total & 215 & 100.0 & 100.0
\end{tabular}

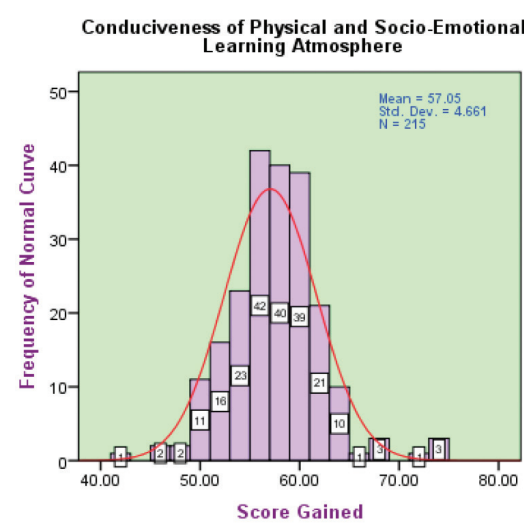

Figure 2. Histogram of Conduciveness of Physical and Socio-Emotional Learning Atmosphere

Second, the scores determined the positive end of the categories, such as excellent to poor within a range of 35 to $73(M=56.33$; $S D=6.222)$ for the diversity of stating agreeableness to other educational backgrounds $\left(\mathrm{X}_{2}\right)$. Of 15 respondents, 9 or $4.1 \%$ respondents answered excellent, 54 or $25.1 \%$ respondents answered good, 91 or $42.3 \%$ answered fair, 45 or $21 \%$ respondents answered unsatisfied, and 16 or $7.4 \%$ respondents answered poor towards lecturers' diversity acceptance among students in the classroom. 
Table 2

Diversity of Stating Agreeableness to Other Educational Backgrounds

\begin{tabular}{lrrr}
\hline \hline Likertr s Scale & Frequency & Percent & Valid Percent \\
& & & \\
\hline 5.00 (Excellent) & 9 & 4.1 & 4.1 \\
4.00 (Good) & 54 & 25.1 & 25.1 \\
3.00 (Fair) & 91 & 42.3 & 50.2 \\
2.00 (Unsatisfied) & 45 & 21 & 21 \\
1.00 (Poor) & 16 & 7.4 & 7.4 \\
$\quad$ Total & 215 & 100.0 & 100.0 \\
& & & \\
\hline \hline
\end{tabular}

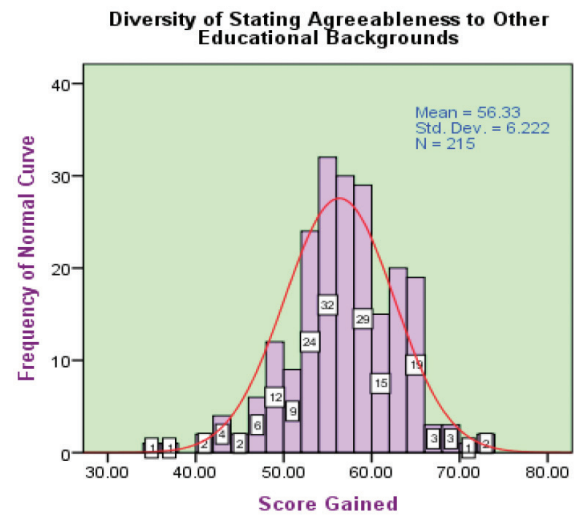

Figure 3. Histogram of Diversity of Stating Agreeableness to other Educational Backgrounds

Third, the scores noted the positive end of the categories, such as excellent to poor within a range of 28 to $68(M=52.00, S D=5.758)$ for the discipline engagement when using time allotment (X3). Of 215 respondents, 24 or $11 \%$ respondents answered excellent, 79 or $37 \%$ respondents answered good, 86 or $40 \%$ respondents answered fair, 17 or $7.9 \%$ respondents answered unsatisfied, and 9 or $4.1 \%$ respondents answered poor towards the discipline engagement when using time allotment.

Table 3

Discipline Engagement when Using Time Allotment

\begin{tabular}{lrrr}
\hline \hline Likert' s Scale & Frequency & Percent & Valid Percent \\
& & & \\
\hline 5.00 (Excellent) & 24 & 11 & 11 \\
4.00 (Good) & 17 & 7.9 & 7.9 \\
3.00 (Fair) & 86 & 40 & 40 \\
2.00 (Unsatisfied) & 79 & 37 & 37 \\
1.00 (Poor) & 9 & 4.1 & 4.1 \\
$\quad$ Total & 215 & 100.0 & 100.0 \\
& & & \\
\hline
\end{tabular}

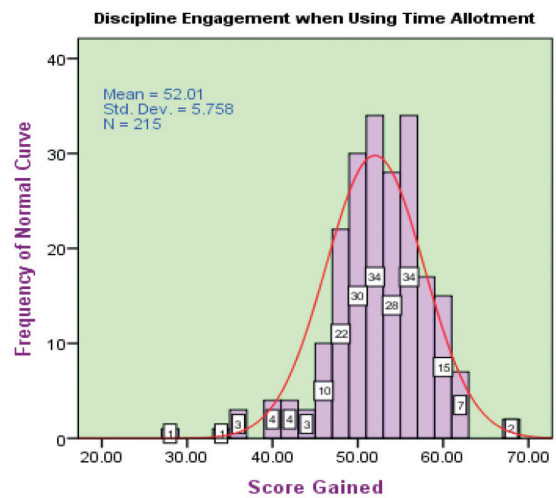

Figure 4. Histogram of Discipline

Engagement when Using Time Allotment

Fourth, the scores claimed at the positive end of the categories, such as excellent to poor within a range of 35 to $70(M=53.79$; $S D=7.260)$ for the corrective decision upon students' inappropriate manner $\left(\mathrm{X}_{4}\right)$. Of 215 respondents, 20 or $9.3 \%$ respondents answered excellent, 49 or $22.7 \%$ respondents answered good, 96 or $45 \%$ respondents answered fair, 37 or $17 \%$ respondents answered 
unsatisfied, and 13 or $6 \%$ respondents answered poor towards the corrective decision on students' inappropriate manner.

Table 4

Corrective Decision upon Students' Inappropriate Manner

\begin{tabular}{lrrr}
\hline \hline Likertr s Scale & Frequency & Percent & Valid Percent \\
\hline 5.00 (Excellent) & & & \\
4.00 (Good) & 49 & 9.3 & 9.3 \\
3.00 (Fair) & 96 & 45 & 22.7 \\
2.00 (Unsatisfied) & 37 & 17 & 45 \\
1.00 (Poor) & 13 & 6 & 17 \\
$\quad$ Total & 215 & 100.0 & 6 \\
& & & \\
& & & \\
\hline \hline
\end{tabular}

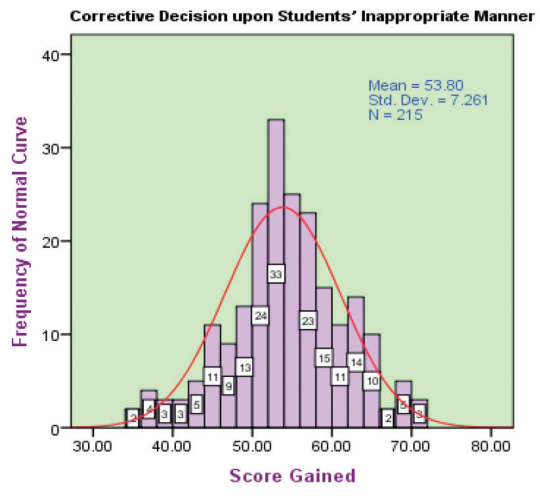

Figure 5. Histogram of Corrective Decision upon Students' Inappropriate Manner

Meanwhile, the dependent variable reflected lecturers' teaching performance in good category, where the scores were indicated in the positive end of the categories clustering from excellent to fair within a range of 40 to $73(M=55.33$; $S D=5.516)$. Of 215 respondents, 63 or $29 \%$ respondents perceived excellent, 122 or $57 \%$ respondents perceived good, and 30 or $14 \%$ respondents perceived fair on lecturers' teaching performance. Table 5 and Figure 3 showed lecturers' teaching performance confirmed as the dependent variable.

Table 5

\section{Lecturers' Teaching Performance}

\begin{tabular}{lrrr}
\hline \hline Likertr s Scale & Frequency & Percent & Valid Percent \\
\hline 5.00 (Excellent) & 63 & 29 & 29 \\
4.00 (Good) & 122 & 57 & 57 \\
3.00 (Fair) & 30 & 14 & 14 \\
$\quad$ Total & 215 & 100.0 & 100.0 \\
& & & \\
\hline \hline
\end{tabular}

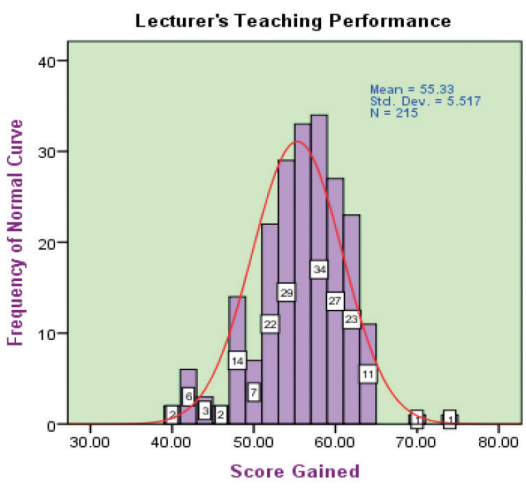

Figure 6. Bar Diagram of Lecturers' Teaching Performance 


\section{Correlations analysis}

Further, the Pearson correlations $(r)$ analyzed the correlation between four predictors or independent variables. It positively and significantly conveyed the corrective decision upon students' inappropriate manner $\left(.285^{* *}, .301^{* *}\right.$, and $\left..203^{* *}\right)$ towards the discipline engagement when using time allotment, and the diversity of stating agreeableness to other educational backgrounds; disciplines engagement when using time allotment $\left(.241^{\star *}\right.$ and $\left..203^{* *}\right)$ towards the diversity acceptance among students; and the corrective decision on students' inappropriate manner $\left(.179^{* *}, .241^{* *}\right.$, and $\left..301^{* *}\right)$ towards the diversity acceptance among students and the corrective decision on students' inappropriate manner. Particularly, the correlational variables were considerably high. In this case, the correlation coefficients among the predictors or independent variables were significant at the level of $p<.01$ for 2-tailed prediction. Its correlation accordingly recorded the values of $.203^{* *}, .301^{\star *}, .241^{\star *}, .179^{\star *}$, and $.285^{* *}$ as summarized in Table 6 .

Table 6

Pearson Correlations (r) among the Independent Variables

\begin{tabular}{llcccc}
\hline \multicolumn{1}{c}{ Predictors } & $\begin{array}{c}\text { Conducive- } \\
\text { ness }\end{array}$ & $\begin{array}{c}\text { Diversity } \\
\text { acceptance }\end{array}$ & $\begin{array}{c}\text { Disciplines } \\
\text { engagement }\end{array}$ & $\begin{array}{c}\text { Corrective } \\
\text { decision }\end{array}$ \\
\hline Conducive- & Pearson Correlation & 1 & $.203^{* *}$ & $.301^{* *}$ & $.285^{\star *}$ \\
ness & Sig. (2-tailed) & & .003 & .000 & .000 \\
& $\mathrm{~N}$ & 215 & 215 & 215 & 215 \\
\hline Diversity & Pearson Correlation & $.203^{\star *}$ & 1 & $.241^{\star *}$ & $.169^{\star}$ \\
acceptance & Sig. (2-tailed) & .003 & & .000 & .013 \\
& $\mathrm{~N}$ & 215 & 215 & 215 & 215 \\
\hline Disciplines & Pearson Correlation & $.301^{* *}$ & $.241^{\star *}$ & 1 & $.179^{\star *}$ \\
engagement & Sig. (2-tailed) & .000 & .000 & & .009 \\
& $\mathrm{~N}$ & 215 & 215 & 215 & 215 \\
\hline Corrective & Pearson Correlation & $.285^{\star *}$ & $.169^{\star}$ & $.179^{\star}$ & 1 \\
decision & Sig. (2-tailed) & .000 & .013 & .009 & \\
& $\mathrm{~N}$ & 215 & 215 & 215 & 215 \\
\hline
\end{tabular}

${ }^{* *}$ Correlation is significant at the .01 level (2-tailed), $p<.01$

* Correlation is significant at the .05 level (2-tailed), $p<.05$

\section{Regression analysis and hypothesis}

These results synchronized the standard multiple regression analyses by addressing the step-wise method. The analyses focused on the linear, multiple regression, and partial correlation results that revealed the effectiveness of lecturers' teaching performance as dealt with the conduciveness of physical and socio-emotional learning atmosphere $(\mathrm{F}=31.256 ; p=.000)$, the diversity of stating agreeableness to other educational 
backgrounds $(\mathrm{F}=25.573 ; p=.000)$, discipline engagement when using time allotment $(\mathrm{F}=37.263 ; p=.000)$, and corrective decision upon students inappropriate manner $(\mathrm{F}=24.073$; $p=.000)$. Table 7 and Figure 7 indicated the multiple regression results, in which the step-wise method statistically formulated its regression equivalence, as follows: $\mathrm{Y}=\mathrm{a}+\mathrm{b} 1 \mathrm{X} 1+\mathrm{b} 2 \mathrm{X} 2+\mathrm{b} 3 \mathrm{X} 3+\mathrm{b} 4 \mathrm{X} 4$ which syntactically equalled to $\mathrm{Y}=12.660+.225 \mathrm{X} 1+$ $.175 \mathrm{X} 2+.237 \mathrm{X} 3+.142 \mathrm{X} 4$, where $\mathrm{a}=$ constant; b1, b2, b3, b4 = regression coefficients. Nevertheless, the scatter plot of lecturers' teaching performance as shown in Figure 7 indicated a weak or low correlation among the predictors or independent variable (X1, X2, $\mathrm{X} 3$, and $\mathrm{X} 4$ ) towards the dependent variable $(\mathrm{Y})$. This result was conditionally relevant to the value of determinant coefficients, where $\mathrm{R}^{2}=.288$ and $p<.05$ that had been collectively contributed the conduciveness of physical and socio-emotional learning atmosphere (X1), the diversity of stating agreeableness to other educational backgrounds (X2), the discipline engagement when using time allotment (X3), and the corrective decision upon students' inappropriate manner (X4).

Table 7

Regression and Partial Correlations Analyses

\begin{tabular}{lccccc}
\hline \multicolumn{1}{c}{ Independent Variables } & $\beta$ & $\mathbf{r}^{\mathbf{2}}$ & $\mathbf{t}$ & $p$ (Sig.) \\
\hline $\begin{array}{l}\text { Conduciveness of physical and socio-emotional learning } \\
\text { atmosphere (X1) }\end{array}$ & .225 & .128 & 2.992 & .003 \\
\hline $\begin{array}{l}\text { Diversity of stating agreeableness to other educational } \\
\text { backgrounds (X2) }\end{array}$ & .175 & .107 & 3.243 & .001 \\
\hline $\begin{array}{l}\text { Disciplines engagement when using time allotment (X3) } \\
\text { The corrective decision upon students' inappropriate } \\
\text { manner (X4) }\end{array}$ & .142 & .102 & 3.045 & .003 \\
\hline $\begin{array}{l}\text { Constant }=12.660 \\
\text { Multiple } R=.536\end{array}$ & $\begin{array}{l}\text { Alpha }(\alpha)=.05 \\
R^{2}(\text { Square })=.288 \\
\text { F } 21.209\end{array}$ & $p=.000$ & & \\
\hline
\end{tabular}

Of the regression analysis above, the research question that derived five hypothesis tests determined that the conduciveness of physical and socio-emotional learning atmosphere $\left(\mathrm{X}_{1}\right)$, the diversity of stating agreeableness to other educational backgrounds $\left(\mathrm{X}_{2}\right)$, the discipline engagement when using time allotment $\left(\mathrm{X}_{3}\right)$, and the corrective decision upon students' inappropriate manner $\left(\mathrm{X}_{4}\right)$ collectively contributed a positive and significant influence towards lecturers' teaching performance $(\mathrm{Y})$, where the output showed $28.8 \%$. Meanwhile, the remainder of other $71.2 \%$ contributing variables still needed to accomplish in the further research as the predictors or independent variables. 


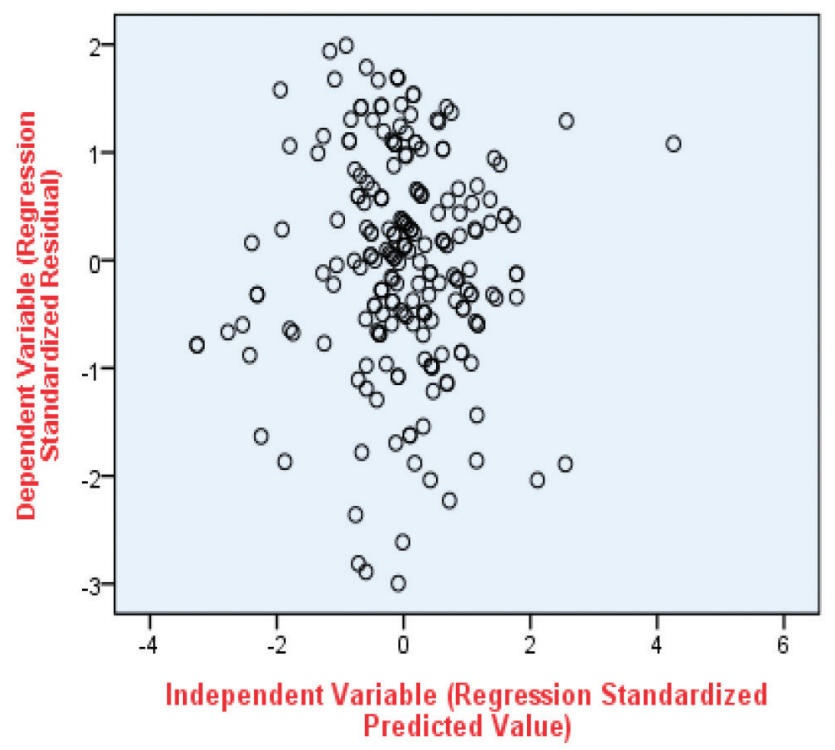

Figure 7. Scatter Diagram of Lecturers' Classroom Management Performance

In this part, the inferential analysis corresponded with the hypothesis tests that determined the predictors or independent variables $\left(\mathrm{X}_{1}, \mathrm{X}_{2}, \mathrm{X}_{3}\right.$, and $\left.\mathrm{X}_{4}\right)$. These predictors had an influence on the dependent variable $(\mathrm{Y})$. First null hypothesis $(\mathrm{H} 0)$ related to $\mathrm{H} 0=$ There was no positive and significant students' perception of the conduciveness of physical and socio-emotional learning atmosphere $\left(\mathrm{X}_{1}\right)$, the diversity of stating agreeableness to other educational backgrounds $\left(\mathrm{X}_{2}\right)$, the discipline engagement when using time allotment $\left(\mathrm{X}_{3}\right)$, and the corrective decision upon students' inappropriate manner towards lecturers' teaching performance $(\mathrm{Y})$ collectively. This could be verifiable that the null hypothesis $(\mathrm{H} 0)=$ There was no positive and significant influence from pre-service English teachers' perception of $\mathrm{X}_{1}, \mathrm{X}_{2}, \mathrm{X}_{3}$, and $\mathrm{X}_{4}$ towards $\mathrm{Y}$ collectively. Hence, the null hypothesis $\left(\mathrm{H}_{0}\right)$ was rejected. It meant that the predictors or independent variables $\left(\mathrm{X}_{1}, \mathrm{X}_{2}\right.$, $\mathrm{X}_{3}$, and $\mathrm{X}_{4}$ ) collectively had a positive and significant influence on the dependent variable (Y). The multiple determinant coefficient $\left(\mathrm{R}^{2}\right)$ was .288 or $28.8 \%$ of lecturers' teaching performance which was determined by students' perception upon four predictors.

Second hypothesis tests stated that $\mathrm{H} 0=$ There was no positive and significant influence between the conduciveness of physical and socio-emotional learning atmosphere $\left(\mathrm{X}_{1}\right)$ towards lecturers' teaching performance $(\mathrm{Y}) . \mathrm{Ha}=$ There was a positive and significant influence between the conduciveness of physical and socio-emotional learning atmosphere $\left(\mathrm{X}_{1}\right)$ towards lecturers' teaching performance $(\mathrm{Y})$. H0 was rejected if the $p$-value was less than $.05(p<.05)$. Apart from the product-moment correlations analysis, it was gained that the conduciveness of physical and socio-emotional learning atmosphere coefficients showed $(\mathrm{R})=.003$ and $p<.05$. Referring to this result $\mathrm{H} 0$ was rejected and Ha was 
acceptable. This could be concluded that the conduciveness of physical and socioemotional learning atmosphere had a contribution towards lecturers' teaching performance, whilst the coefficients $(\mathrm{R})=.003$ showed a positive correlation. The conduciveness of physical and socio-emotional learning atmosphere could be concisely interpreted that students were more likely to have a positive physical and socio-emotional learning with their lecturers when lecturers appraised constructive and performance-based compliments and addressed efforts whilst abolishing to afflict students for obtaining right responses during following classes. To be engaged in learning, the extrinsically skillful students were motivated to be more autonomous in terms of getting attractive and supportive activities physically and socially. On the other hand, the anxious students about getting involved in exercising various assignment needed to be more structured building of learning guidance and more specific and effective teaching strategies to take part in the classroom learning entirely. The condition might be identified through the use of self-regulatory approaches when students were provoked to participate inside the classroom discussion. In this learning circumstance, the lecturers attempted to create a sense of mutual care for students' learning objectives.

Third hypothesis tests stated that $\mathrm{H} 0=$ There was no positive and significant influence between the diversity of stating agreeableness to other educational backgrounds $\left(\mathrm{X}_{2}\right)$ towards lecturers' teaching performance $(\mathrm{Y}) . \mathrm{Ha}=$ There was a positive and significant influence between the diversity of stating to other educational backgrounds $\left(\mathrm{X}_{2}\right)$ towards lecturers' teaching performance $(\mathrm{Y})$. $\mathrm{H} 0$ was rejected if the $p$-value was less than $.05(p<.05)$. Apart from the product-moment correlations analysis, it was gained that the diversity acceptance among students' coefficients showed $(\mathrm{R})=.001$ and $p<.05$. Referring to this result, $\mathrm{H} 0$ was rejected and Ha was acceptable. This could be concluded that the diversity of stating agreeableness to other educational backgrounds had a contribution towards lecturers' teaching performance, whilst the coefficients $(\mathrm{R})=.001$ showed a positive correlation. This variable reasonably accomplished that the diversity of stating agreeableness to students' educational backgrounds positively concerned with the openness of facing the universally oriented diversity. The lecturers' agreeableness advocated and supported teaching and pedagogy affairs. This agreeableness was to align and describe classroom's learning activities that depicted the mainstream of educational and pedagogical cultures. On the other hand, students' diversity was potentially exposed in both good and bad positions since diversity led to be more standard in mature matters. However, classes greatly matched with all activities for discussions about respectfulness, tolerance, awareness, and importance of other diversity values for students - students or students - lecturers communications.

Fourth hypothesis tests stated that $\mathrm{H} 0=$ There was no positive and significant influence between the discipline engagement when using time allotment $\left(\mathrm{X}_{3}\right)$ towards lecturers' teaching performance $(\mathrm{Y}) . \mathrm{Ha}=$ There was a positive and significant influence between the discipline engagement when using time allotment $\left(\mathrm{X}_{3}\right)$ towards lecturers' teaching 
performance (Y). H0 was rejected if the $p$-value was less than .05 $(p<.05)$. Apart from the product-moment correlations analysis, it was gained that the discipline engagement when using time allotment coefficients showed $(\mathrm{R})=.000$ and $p<.05$. Referring to this result $\mathrm{H} 0$ was rejected and $\mathrm{Ha}$ was acceptable. This could be concluded that the discipline engagement when using time allotment had a contribution to lecturers' teaching performance, whilst the coefficients $(\mathrm{R})=.000$ showed a positive correlation. The discipline engagement when using time allotment relied on the successful lecturers who arranged a well teaching procedure whilst minimizing wasteful time to maximize an effective learning opportunity. An effective and efficient lecturer might manage his or her instructional minutes per teaching session instead of wasting the time. It was considerably regarded that lecturers' best instruction sessions would depend on good times allocated and manageable with students in the classroom. So far, a good classroom procedure using time allotment was constituted with the basic element for students' learning circumstances. Hence, lecturers contextually needed to allocate an efficient teaching procedure for every detail in their classroom. This conveyed the routine activities such as doing apperception routinely, starting the lesson, leading class discussion, providing assignment, and concluding the session.

The fifth hypothesis tests stated that $\mathrm{H} 0=$ There was no positive and significant influence between the corrective decision upon students' inappropriate manner $\left(\mathrm{X}_{4}\right)$ towards lecturers' teaching performance $(\mathrm{Y}) . \mathrm{Ha}=$ There was a positive and significant influence between the corrective decision upon students' inappropriate manner $\left(\mathrm{X}_{4}\right)$ towards lecturers' teaching management performance $(\mathrm{Y})$. Ho was rejected if the $p$-value was less than $.05(p<.05)$. Apart from the product-moment correlations analysis, it was gained that the corrective decision on students' inappropriate manner $(\mathrm{R})=.003$ and $p<.05$. Referring to this result $\mathrm{H} 0$ was rejected and Ha was acceptable. This could be concluded that the corrective decision upon students' inappropriate manner had a contribution to lecturers' teaching performance, whilst the coefficients $(\mathrm{R})=.003$ showed a positive correlation. The corrective decision upon students' inappropriate manner brought about the objectives of compensating for students' actions in the classroom. The lecturers' corrective decision aimed at contending with students' academic and non-academic performance better, rather than giving a punishment. The corrective decision coincided with the verbal and written warnings that assisted students to be more well-performed academic achievements and to coach students' inappropriate behaviors. The lecturers needed to induce students to set rules in the classroom that dealt with students' inappropriate manner through lecturers' corrective decision. The consequence of advocating lecturers' corrective decision, the classroom was expected to be conducive regarding the management and discipline matters. 


\section{Discussion}

The descriptive statistics analysis verified the results of the conduciveness of physical and socio-emotional learning atmosphere $\left(\mathrm{X}_{1}\right)$, the diversity of stating agreeableness to other educational backgrounds $\left(\mathrm{X}_{2}\right)$, the discipline engagement when using time allotment $\left(\mathrm{X}_{3}\right)$, the corrective decision upon students' inappropriate manner $\left(\mathrm{X}_{4}\right)$, and lecturers' teaching performance $(\mathrm{Y})$, by measuring through the Likert's rating scale. The lecturers' teaching performance analysis was on the effective category with 122 or $57 \%$ respondents. Data analysis results were gained through $\mathrm{R}=.536 ; \mathrm{F}=21.209$; and $p=.000$ with the equivalence regression, $\mathrm{Y}=12.660+.225 \mathrm{X}_{1}+.175 \mathrm{X}_{2}+.237 \mathrm{X}_{3}+.142 \mathrm{X}_{4}$. Each independent variable contributed $22.5 \%$ for the conduciveness of physical and socio-emotional learning atmosphere $\left(\mathrm{X}_{1}\right)$, $17.5 \%$ for the diversity of stating agreeableness to other educational backgrounds $\left(\mathrm{X}_{2}\right)$, $23.7 \%$ for the discipline engagement when using time allotment $\left(\mathrm{X}_{3}\right)$, and $14.2 \%$ for the corrective decision upon students' inappropriate manner $\left(\mathrm{X}_{4}\right)$. Meanwhile, the predictors $\left(\mathrm{X}_{1}, \mathrm{X}_{2}, \mathrm{X}_{3}\right.$, and $\left.\mathrm{X}_{4}\right)$ contributed $28.8 \%$ towards lecturers' teaching performance $(\mathrm{Y})$.

Being part of the regression analysis, the partial analysis firstly noted the significance level of the conduciveness of physical and socio-emotional learning atmosphere $(\mathrm{t}=2.992 ; p=.003)$ with the equivalence regression, $\mathrm{Y}=31.172+.225 \mathrm{X}_{1}$ and was categorized into the lowest level. The result was on fair category with the highest score was 74 , in which this was equivalent to 108 or $50.2 \%$ respondents who responded to this variable $\left(\mathrm{X}_{1}\right)$. Regarding the conduciveness of physical and socio-emotional learning atmosphere, Wright (2005) pointed out that the language used by lecturers used to be entangled with the physics difficulties in managing the large class. It was mostly subjected to lecturers' existing instruction and responsibility to set as the best practice in the classroom (Barak, 2017) that engaged with the sustainability of classroom management in the long term (Marlow, Hansford, Edwards, Ukoumunne, Norman, Ingarfield, Sharkey, Logan, \& Ford, 2015). Classroom management addressed the use of time and space, instructional strategies, and building effective relationships between students and lecturers (Blackburn \& Hays, 2014). As indicated in the fair category, the classroom conduciveness relied on the verbal and physical responses appropriately or inappropriately (Marzano, Gaddy, Foseid, Foseid, \& Marzano, 2005). Alternatively, lecturers' self-confidence might dominate the instruction concept in adjudging the instances day-to-day (Sadler, 2013). The conduciveness of physical and socio-emotional learning atmosphere contained lecturers' ability in managing the class when the lecture ran, lecturers' effective responses when handling students' in-disciplinary, lecturers' ability in creating harmonious learning, so that students were comfortable to join the classes, and lecturers' understanding students' emotional stability. According to Sadler (2013), lecturers might actively involve students became creative through the teaching and learning context to contemplate increased opportunities for interaction. 
Next, the partial analysis recorded the significance level of the diversity of stating agreeableness to other educational backgrounds $(\mathrm{t}=3.243 ; p=.001)$ with the equivalence regression, $\mathrm{Y}=38.977+.175 \mathrm{X}_{2}$ and was categorized into the second level. The result indicated fair category with the highest score was 73 , in which this was equivalent to 91 or $42.3 \%$ respondents who responded to this variable $\left(\mathrm{X}_{2}\right)$. The diversity of stating agreeableness to other educational backgrounds related to the increase of classroom diversity that had not been created immediately (Cummings, 2000). So far, classroom management was understood to influence and control students' behavior primarily in disciplines (Allen, 2010). However, the lecturers ensured that the students addressed the rationale, objectives and pedagogical parameters in the classroom (McCabe \& O'Connor, 2014). The lecturers might start to scaffold students' learning through explicit teaching and evidence that indicated the quality of communicative interaction (O’Neill \& Geoghegan, 2011). Herein, the diversity of stating agreeableness to other educational backgrounds involved lecturers' adaptive understanding towards the complexity of their class situation, lecturers' identification among individual students' diversity, the capability of lecturers' problem-solving, and the sustainable maintenance efforts towards their class' multiple diversities. However, to manage students' diversity in the classroom, lecturers had better go with their positive emotions of teaching that included joy, satisfaction, and pleasure, besides being aware of their tough frustration, anger, and anxiety in the classroom as well. Notwithstanding allied, self-confidence shows as a split proportion to emotions (Sutton \& Wheatley, 2003; Sadler, 2013).

Then, the partial analysis documented the significance level of the discipline engagement when using time allotment $(t=3.968 ; p=.000)$ with the equivalence regression, $\mathrm{Y}=36.103+.237 \mathrm{X}_{3}$ and was categorized into the first level. The result reached fair category with the highest score was 68 , in which this was equivalent to 86 or $40 \%$ respondents who responded to this variable $\left(\mathrm{X}_{3}\right)$. The discipline engagement when using time allotment showed the most significant result among other three predictors in this study. The indicators relied on lecturers' discipline when handling multitasking and responsibility, allocating time effectively and efficiently, addressing comprehensive strategies during the classes, and sharing time allocation when being involved students. This condition corresponded with Lochner and Gijselaers' (2011) claims, in which lecturers potentially tended to return their teaching habits if they were not comfortable with the undertaking model of teaching. In this case, a classroom management issue ranged from discipline and behaviors management (Blackburn \& Hays, 2014). It meant that the discipline engagement attempted to drive the domain and adaption of individual students effectively (Emmer \& Stough, 2001) by optimizing time on the classroom-based tasks (Cunningham, 2009) and to set the stage for either academic or social-emotional learning from lecturers' emotional supports as well as students' learning accomplishment (Garwood \& Feagans, 2017).

Finally, the partial analysis addressed the significance level of the corrective decision on students' inappropriate manner $(\mathrm{t}=3.045 ; p=.003)$ with the equivalence regression, 
$\mathrm{Y}=42.304+.142 \mathrm{X}_{4}$ and was categorized into the third level. The result earned on fair category with the highest score was 70 , in which it was equivalent to 96 or $45 \%$ respondents who responded to the variable $\left(\mathrm{X}_{4}\right)$. The corrective decision on students' inappropriate manner showed a moderately significant result among other three predictors. The lecturers' corrective decision regarded the ability to respond and manage with the instruction activities, pointed pre-notices and warns to students when misconducting in the classroom, decided a punishment when students continually violated the rules of learning and determined problem mitigation that existed among students via discussion engagement. This situation, according to McAfee (2015) could be happening with lecturers' mutual interest in students' affairs. If a lecturer took interest in students' awareness and individual accomplishments, students would become more comfortable and respectful. Their confidence could be noticed through physical gestures and movement, positive interaction, affirmative reactions, proportional, and appropriate good behaviors. When the corrective decision on students' inappropriate manner was a part of the classroom management setting, lecturer's roles was to drive the substance of priority in ensuring students' motivation and participation (McCabe \& O'Connor, 2014), besides emphasizing more student-centered approaches and beliefs that they accomplished a good learning experience of subjects while attending the classes (Sadler, 2013).

Of lecturers' instruction effectiveness toward students' learning necessities, it became self-regulated learning mechanism (Emmer \& Stough, 2001), in which the classroom management-focused the meta-skill integrating students' cognitive perception on being proactive, ecological-systemic, and leadership-oriented, self-regulation skills, and interpersonal relationships (Tal, 2010). The effectiveness regarded to the teaching strategies involving the meaningful content, powerful teaching strategies, and an organizational structure (Allen, 2010), because the main change during lecturers' teaching performance takes on a stage, responding to students' multiple behaviors to a substantial point they could initiate confidently (Barnes, 2006). The classroom management considered all things relating to the influential factors on hard and soft skills for determining success (Blackburn \& Hays, 2014), and ideally represented a significant input and output of lecturers' pedagogical knowledge (Emmer \& Stough, 2001).

\section{Conclusion}

Beyond the pedagogical practices, this conclusion withdraws the determinants relating to the conduciveness of physical and socio-emotional learning atmosphere, the diversity of stating agreeableness to other educational backgrounds, the discipline engagement when using time allotment, and the corrective decision upon students' inappropriate manner. All determinants show that lecturers' teaching performance places in fair category when addressing the classroom management. However, these determinants either partially 
or collectively have a positive and significant influence on the effectiveness of lecturers' teaching performance. Realizing the empirical lecturers' teaching performance, this study accomplishes respondents' rating subjectivity as well when fulfilling the self-rated questionnaire. The questionnaire does not specifically accommodate lecturers' teaching professional experiences and academic backgrounds. Hence, being generalized by some respondents in fulfilling the questionnaire is still realizably found since the procedure of fulfilling the questionnaire addresses the supervisory rating method, in which this study merely depends on respondents' entirely perception of lecturers' teaching performance. However, this study contributes $28.8 \%$ of the total pedagogical practices in lecturers' teaching performance that provides four determinants. Meanwhile, other determinants totaling $71.2 \%$ of lecturers' teaching performance criteria can be still identifiable from the other perspectives of the classroom management in the future research.

\section{References}

Allen, K. P. (2010). Classroom management, bullying, and teacher practices. The Professional Educator, 34(1), 1-15.

Barak, M. (2017). Science teacher education in the twenty-first century: A pedagogical framework for technology-integrated social constructivism. Research in Science Education, 47(2), 283-303. doi: 10.1007/s11165-015-9501-y

Barnes, R. (2006). The practical guide to primary classroom management. London: Paul Chapman Publishing.

Blackburn, H., \& Hays, L. (2014). Classroom management and the librarian. Education Libraries, 37(1-2), 23-32. doi: 10.26443/el.v37i1-2.339

Chambers, S. M., \& Hardy, J. C. (2005). Length of time in student teaching: Effects on classroom control orientation and self-efficacy beliefs. Educational Research Quarterly, 28(3), 3-9.

Coakes, S. J., \& Steed, L. G. (2007). SPSS: Analysis without anguish: Version 14.0 for windows. Brisbane: John Wiley \& Sons Australia, Ltd.

Cohen, J. (1977). Statistical power analysis for the behavioral sciences (Rev. ed.). New York: Academic Press.

Cummings, C. (2000). Winning strategies for classroom management. Alexandria, VA: Association for Supervision and Curriculum Development (ASCD).

Cunningham, G. (2009). The new teacher's companion: Practical wisdom for succeeding in the classroom. Alexandria, VA: Association for Supervision and Curriculum Development (ASCD).

Eisenman, G., Edwards, S., \& Cushman, C. A. (2015). Bringing reality to classroom management in teacher education. The Professional Educator, 39(1), 1-12.

Emmer, E. T., \& Stough, L. M. (2001). Classroom management: A critical part of educational Psychology, with implications for teacher education. Educational Psychologist, 36(2), 103-112. doi: 10.1207/S15326985EP3602_5 
Fernandes, F., Flores, M. A., \& Lima, R. M. (2012). Students' views of assessment in project-led Engineering education: Findings from a case study in Portugal. Assessment and Evaluation in Higher Education, 37(2), 163-178. doi: 10.1080/02602938.2010.515015

Garwood, J. D., \& Feagans, L. V. (2017). Classroom management affects the literacy development of students with emotional and behavioral disorders. Exceptional Children, 83(2), 123-142. doi: 10.1177/0014402916651846

Ghozali, I. (2001). Aplikasi analisis multivariate dengan program SPSS. Semarang: Badan Penerbit Universitas Diponegoro.

Ivanov, D. (2014). Becoming a good teacher of English. Euromonitor Journal, 5(1), 40-46.

Korpershoek, H., Harms, T., de Boer, H., van Kuijk, M., \& Doolaard, S. (2014). Effective classroom management strategies and classroom management programs for educational practice: A metaanalysis of the effects of classroom management strategies and classroom management programs on students' academic, behavioural, emotional, and motivational outcomes. Groningen: RUG/ GION.

Lenaerts, F., Braeye, S., Nguyen, T. L, H., Dang, T. A., \& Vromant, N. (2017). Supporting teachers in Vietnam to monitor preschool children's wellbeing and involvement in preschool classrooms. International Journal of Early Childhood, 49(2), 245-262. doi: 10.1007/s13158-017-0188-2

Lochner, L., \& Gijselaers, W. H. (2011). Improving lecture skills: A time-efficient 10-step pedagogical consultation method for medical teachers in healthcare professions. Medical Teacher, 33, 131-136. doi: 10.3109/0142159X.2010.498490

Marlow, R., Hansford, L., Edwards, V., Ukoumunne, O., Norman, S., Ingarfield, S., Sharkey, S., Logan, S., \& Ford, T. (2015). Teaching classroom management-A potential public health intervention? Health Education, 115(3/4), 230-248. doi: 10.1108/HE-03-2014-0030

Marzano, R. J., Gaddy, B. B., Foseid, M. C., Foseid, M. P., \& Marzano, J. S. (2005). A handbook for classroom management that works. Alexandria, VA: Association for Supervision and Curriculum Development (ASCD).

Marzano, R. J., Marzano, J. S., \& Pickering, D. J. (2003). Classroom management that works: Research-based strategies for every teacher. Alexandria, VA: Association for Supervision and Curriculum Development (ASCD).

McAfee, M. (2015). Classroom management plan for the secondary classroom. Retrieved August 15, 2018, from https://edsc658-458.community.uaf.edu/files/2015/12/McAfeeM_EDSC658_ CM-Plan.pdf

McCabe, A., \& O'Connor, U. (2014). Student-centered learning: The role and responsibility of the lecturer. Teaching in Higher Education, 19(4), 350-359. doi: 10.1080/13562517.2013.860111

O’Neill, S., \& Geoghegan, D. (2014). First-year pre-service teachers' views about literacy: Exploring the breadth and depth of their pedagogical needs. International Journal of Pedagogies and Learning, 6(3), 187-205. doi: 10.5172/ijpl.2011.6.3.187

Pallant, J. (2011). SPSS survival manual: A step by step guide to data analysis using SPSS (4th Ed.). Crows Nest, New South Wales: Allen \& Unwin. 
Reinke, W. M., Stormont, M., Webster-Stratton, C., Newcomer, L. L., \& Herman, K. C. (2012). The incredible year's teacher classroom management program: Using coaching to support generalization to real-world classroom settings. Psychology in the Schools, 49(5), 416-428. doi: $10.1002 /$ pits. 21608

Romi, S., Lewis, R., \& Roache, J. (2013). Classroom management and teachers' coping strategies: Inside classrooms in Australia, China, and Israel. Quarterly Review of Comparative Education, XLIII(1), 4-19. doi: 10.1007/s11125-013-9271-0

Sadler, I. (2013). The role of self-confidence in learning to teach in higher education. Innovations in Education and Teaching International, 50(2), 157-166. doi: 10.1080/14703297.2012.760777

Santoso, S. (2001). Mengolah data statistik secara profesional. Jakarta: PT. Alex Media Komputindo.

Selçuk, G., Kadi, A., Yildirim, R., Çelebi, N. (2017). A study on teacher candidates' competencies in classroom management. Acta Didactica Napocensia, 10(4), 63-68. doi: 10.24193/adn.10.4.7

Shindler, J. (2010). Transformative classroom management: Positive strategies to engage all students and promote a psychology of success. San Francisco: Jossey-Bass Teacher Series.

Sumekto, D. R., \& Setyawati, H. (2020). Revealing lecturer's paralinguistic attribution: How the visual manner contributes to students' non-cognitive skills. Indonesian Journal of Applied Linguistics, 9(3), 559-571. doi: 10.17509/ijal.v9i3.23206

Sumekto, D. R., \& Setyawati, H. (2018). Students' descriptive writing performance: The analytic scoring assessment usage. Cakrawala Pendidikan, 37(3). 413-425. doi: 10.21831/cp.v38i3.20033

Sumekto, D. R. (2017). The effectiveness of pre-service English teachers' collaborative genre-based writing feedback. Lingua Cultura, 11(1), 31-38. doi: 10.21512/lc.v11i1.1595

Sutton, R. E., \& Wheatley, K. F. (2003). Teachers' emotions and teaching: A review of the literature and directions for future research. Educational Psychology Review, 15(4), 327-358. doi: 10.1023/A:1026131715856

Tal, C. (2010). Case studies to deepen understanding and enhance classroom management skills in preschool teacher training. Early Childhood Education Journal, 38(2), 143-152. doi: 10.1007/ s10643-010-0395-z

Webster-Stratton, C., Reid, J. M, \& Stoolmiller, M. (2008). Preventing conduct problems and improving school readiness: Evaluation of the incredible year's teacher and child training programs in high-risk schools. Journal of Child Psychology and Psychiatry, 49(5), 471-488. doi: 10.1111/j.1469-7610.2007.01861.x

Webster-Stratton, C., Reinke, W. M., Herman, K. C., \& Newcomer, L. L. (2011). The incredible year's teacher classroom management training: The methods and principles that support the fidelity of training delivery. School Psychology Review, 40(4), 509-529. doi: 10.1080/02796015.2011.12087527

Wright, T. (2005). Classroom management in language education. New York: Palgrave Macmillan. 


\title{
Klasės (auditorijos) valdymo veiksniai kaip mokymo triukai
}

\author{
Didik Rinan Sumekto ${ }^{1}$, Heny Setyawati ${ }^{2}$, Tukiyo ${ }^{3}$, Ronggo Warsito ${ }^{4}$
}

1 Widya Dharma universitetas, Anglų kalbos ugdymo katedra, Ki Hajar Dewantara, Klateno Utara, Klatenas, Indonezija, didikrinan@unwidha.ac.id

2 Semarango Valstybinis universitetas, Kūno kultūros ugdymo katedra, Sekarano universiteto miestelis, Gunungpati, Semarangas, Indonezija, henysetyawati@mail.unnes.ac.id

3 Widya Dharma universitetas, Javos švietimo departamentas, Ki Hajar Dewantara, Klateno Utara, Klatenas, Indonezija, tukiyo@unwidha.ac.id

4 Widya Dharma universitetas, Pilietinio ugdymo skyrius, Ki Hajar Dewantara, Klateno Utara, Klatenas, Indonezija, warsito@unwidha.ac.id

\section{Santrauka}

Klasès (auditorijos) valdymas tampa ne tik studentų ir dėstytojų akademinių, bet ir neakademinių bendravimo igūdžių esminiu laimèjimu. Šiame tyrime dẻmesys sutelkiamas i dèstytojų gebejimą valdyti klasę (auditoriją) siekiant atsakyti ị šiuos klausimus: ar dėstytojų palankumas, îvairovès prièmimas, disciplinos laikymasis ir korekcinis sprendimas dèl netinkamo studentų būdo iš dalies ir iš esmès daro teigiamą ir reikšmingą poveikị dėstytojų mokymo vaidmeniui.

Šiuo tyrimu buvo siekiama ịvertinti dėstytojų mokymo vaidmenį lemiančius veiksnius, kurie svarbūs aukštojo mokslo studentams. Tyrime savanoriškai dalyvavo 215 (18,69 proc.) būsimųjų anglų kalbos mokytojų (angl. PSETs (pre-service English teachers)). Duomenys buvo renkami paprastos atsitiktinės atrankos būdu, t. y. kiekvieną semestrą buvo atrenkami respondentai ir jiems pateikiamas klausimynas pagal Likerto 5 balų vertinimo skalę. Analizuojat duomenis kiekybiškai, buvo naudojama aprašomoji statistika, Pirsono koreliacijos ir regresijos analizè, kur reikšmingumo lygmuo 0,05. Šiuo tyrimu buvo pasiektas laipsniškas ekvivalentiškumas taikant tiesinę regresinę analizę. Palankumas, ịvairovès prièmimas, disciplinos laikymasis ir korekcinis sprendimas - tai lemiantys veiksniai, kurie iš dalies (28,8 proc. nuo visos dèstymo veiklos) turejjo teigiamą ir reikšmingą ịtaką dèstytojų mokymo vaidmenims. Kitus veiksnius, iš viso 71,2 proc. dėstytojų mokymo vaidmens kriterijų bus galima atpažinti iš kitų klasės (auditorijos) valdymo perspektyvų ateityje.

Esminiai žodžiai: palankumas, korekcinis sprendimas, drausmès laikymasis, ivairovès priemimas.

Gauta 20200317 / Received 17032020

Priimta 20200910 / Accepted 10092020 